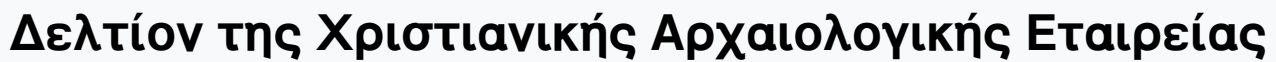

Tó 31 (2010)

$\Delta \varepsilon \lambda$ tíov XAE 31 (2010), Пврі́обоৎ $\Delta^{\prime}$

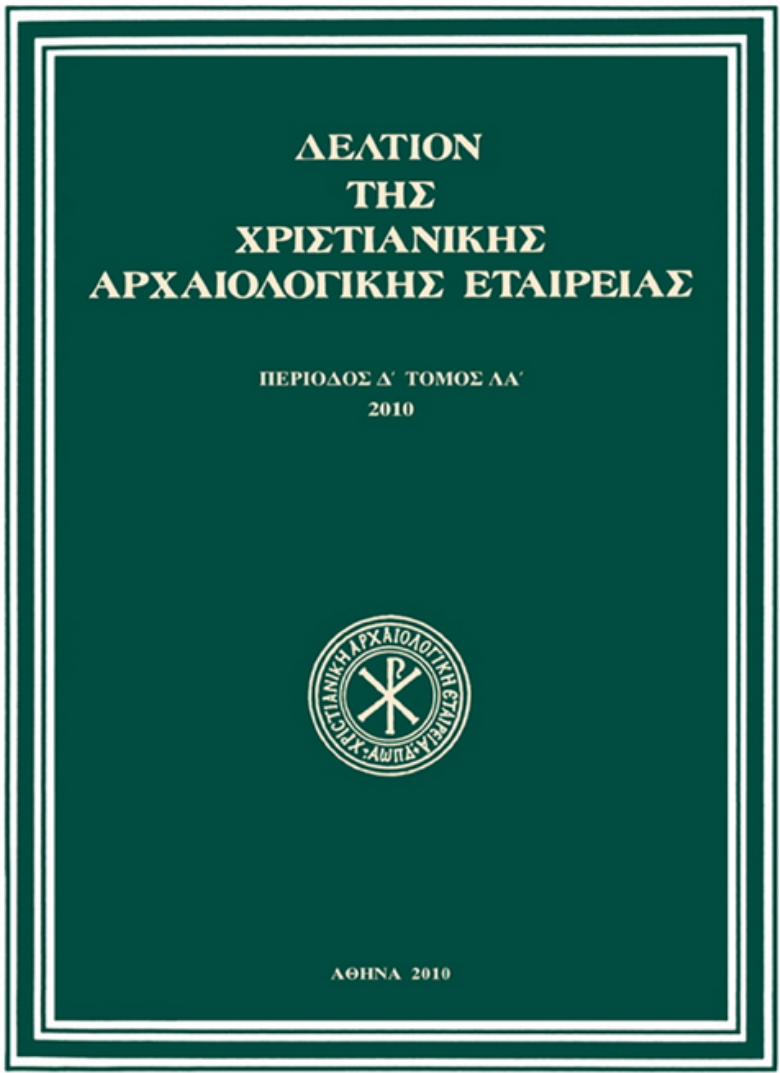

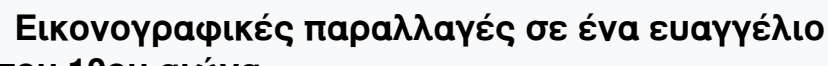
Tou 10ou alẃva

Ellen C. SCHWARTZ

doi: $\underline{10.12681 / \text { dchae. } 671}$

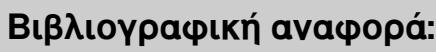

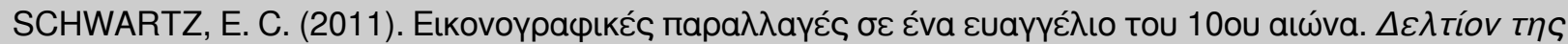

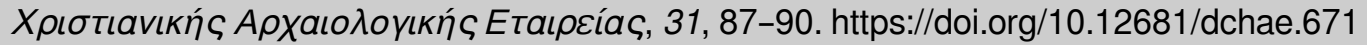




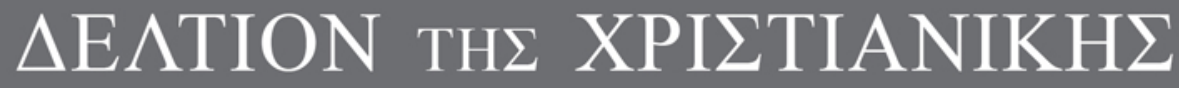 APXAIO $\Lambda$ ОГКН $\Sigma$ ETAIPEIA $\Sigma$}

Iconographic Variation in a Tenth-century Evangelion

Ellen SCHWARTZ

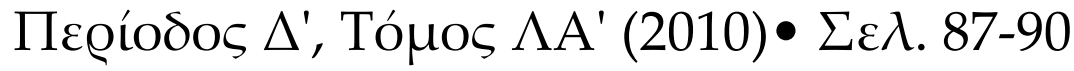
A@HNA 2010 


\section{ICONOGRAPHIC VARIATION IN A TENTH-CENTURY EVANGELION}

$\mathrm{S}_{\mathrm{i}}$ Catherine's monastery for its beauty and interesting iconographic features ${ }^{1}$. Produced ca. 975-1000 A.D. ${ }^{2}$, the book is an evangelion or lectionary, a gospel book with passages arranged according to the church calendar. The manuscript consists of 204 folios of parchment, $21.8 \times 29 \mathrm{~cm}$ in size. The gold uncial script, $.5 \mathrm{~cm}$ high, is arranged in two columns on each page with 16 lines to a column. There are elaborate headpieces separating the five sections of the lectionary; ornamentation of the text pages is restrained, consisting of outlined letters decorated with leaves. Like the text, the decoration is all executed in gold.

The glory of the manuscript is its collection of miniatures grouped at the beginning. These include Christ (page 1), the Virgin (page 3, Fig. 1), an unknown saint named Peter (page 5, Fig. 2), as well as the four evangelists - Matthew on page 8 , Mark on 10 , Luke on 12 , and John on $14^{3}$. The majority of

\footnotetext{
${ }^{1}$ A preliminary version of this material was presented at the XVII International Byzantine Studies Congress, Washington, D.C. August 1986. The manuscript in question has been documented at Mt. Sinai since 1827. It seems to have been earlier in the monastery of the Pantocrator in Constantinople, where it was noted by the Russian pilgrims Deacon Ignatii and Metropolit Pimen in 1389. V. N. Beneshevic, Pamiatniki Sinaia arkheologicheskie i paleograficheskie I, Leningrad 1925, 47. Several scholars suggest, due to the high quality of the illustrations, abbreviation of the pericopes or readings, as well as the lack of wear, that this volume was made originally as an altar implement or holy relic and not a text to be used. See K. Weitzmann and G. Galavaris, The Monastery of St Catherine at Mt. Sinai. The Illustrated Greek Manuscripts I, From the Ninth to the Twelfth Century, Princeton 1990, 46, and K. A. Manafis (ed.), Sinai, Treasures of the Monastery of St. Catherine, Athens 1990, 314. Most recently, the manuscript has been discussed in Father Justin Sinaites' essay, "The Sinai Codex Theodosianus: Manuscript as Icon," in R.S. Nelson and K.M. Collins (eds), Holy Image, Hallowed Ground: Icons from Sinai, Los Angeles 2006, 56-77, and as catalogue no. 7, 139-139 with older bibliography.

2 The manuscript was dated through a comparison to Turin Univ. Lib. cod. B.I,2. See K. Weitzmann, Die byzantinische Buchmalerei des 9. und
}

these portraits fall comfortably within the canon of frontispiece portraits at this time - a single standing figure against a square gold-leaf background ${ }^{4}$. The contrapposto stance, skilled modeling, and muted color scheme of most of these figures create a sense of three-dimensional reality. The depictions of two figures, however, stand out as unusual, and allow speculation as to the creative use of models in their formulation.

The figure of Peter (Fig. 2) is the most enigmatic. Labeled OCIOC ПIETPOC, he remains unidentified. Weitzmann has suggested that he represents Peter of Monobata, a holy man mentioned on a calendar which he associates with the Sinai manuscript ${ }^{5}$. Distinct from the other representations, Peter is rendered in a flat, frontal, symmetrical pose. His garments are painted in subdued tones of gray and brown. The style of the Peter portrait foreshadows the ascetic, monastic style which will flower in the eleventh century, especially in manu-

10. Jahrhunderts, Berlin 1935, 28 , and also Weitzmann and Galavaris, op.cit., 42. This date has been accepted by current scholars: see L. Safran (ed.), Heaven on Earth, Art and the Church in Byzantium, University Park, PA 1998, 222 and Manafis, op.cit., 314. In the catalogue of the Sinai exhibition, the manuscript is given the date range of $975-1000$, bolstered by comparison to manuscripts made for emperor Basil II at that time. See Nelson and Collins, op.cit., 137-138.

${ }^{3}$ The manuscript is paginated, not foliated, hence the numbering.

${ }^{4}$ These illustrations, as well as examples of text pages and ornament, are gorgeously reproduced in Holy Image, Hallowed Ground, in both Father Justin's article and the catalogue entry, cf. supra. On evangelist portrait types, see A.M. Friend, "The Portraits of the Evangelists in Greek and Latin Manuscripts 1," Art Studies V (1927), 115-147 and VII (1929), 3-29.

${ }^{5}$ The synaxarium of the lectionary displays a rich decoration for the lesson of February 7, the calendar day for this holy man (Weitzmann and Galavaris, op.cit., 45). Other suggestions, such as those by Beneshevic, are less convincing (Beneshevic, op.cit., 46-47). The holy man Peter and the monastery of Monobata are discussed most recently in Nelson and Collins, op.cit., 66-67. 


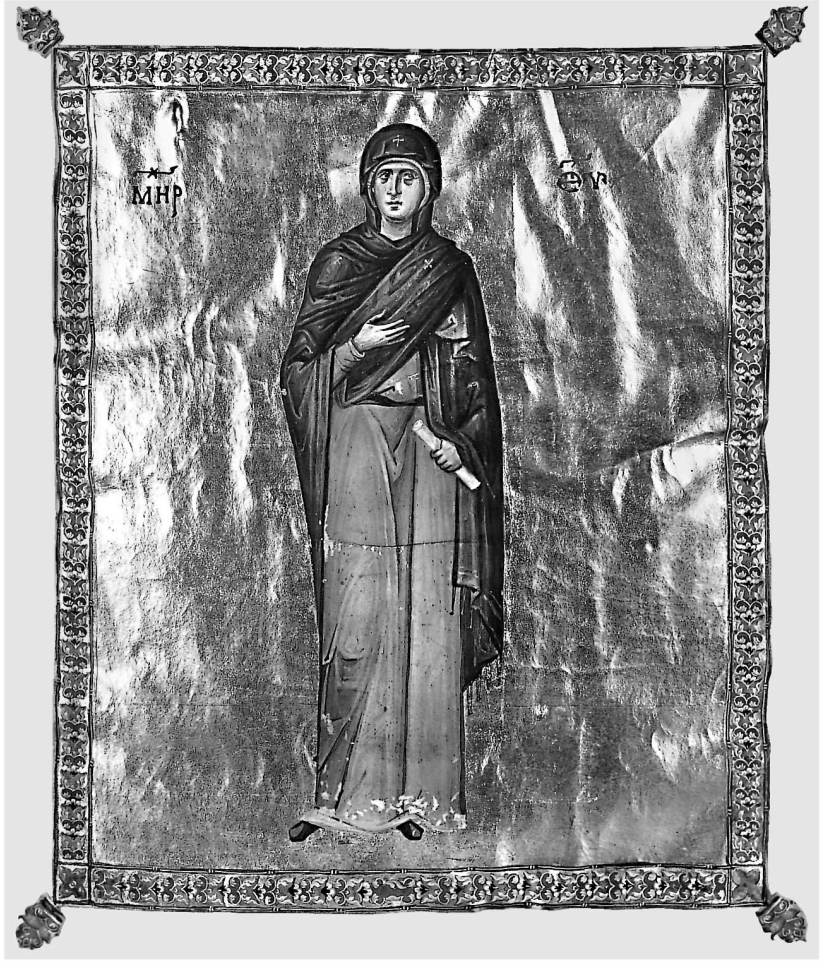

Fig. 1. Virgin, Sinai gr. 204, page 3, c. 1000 (Published through the courtesy of the Michigan-Princeton-Alexandria Expedition to Mt. Sinai).

scripts of the Heavenly Ladder of John Climacus ${ }^{6}$. This figure does, however, fit within a contemporary tradition - that of menologion illustration. The style of the figure, however, is most similar to the rendering of figures deceased rather than living. Saints on biers are almost always shown in this flat, dematerialized, and symmetrical manner. A good comparison is provided by the figure of St. Ignatius of Constantinople from the Menologion of Basil II painted at the end of the tenth century (Fig. 3) ${ }^{7}$. The painter of Sinai gr. 204, to stress the monastic qualities of this saint, may have searched for a non-classical mode of representation to differentiate him from the remaining portraits ${ }^{8}$. Or he may have wanted to

\footnotetext{
${ }^{6}$ See J. R. Martin, The Illustration of the Heavenly Ladder of John Climacus, Princeton 1954, esp. 150-163.

${ }^{7}$ See Il Menologio di Basilio II (Cod. Vaticano Greco 1613), vol. II, Turin 1907 , fig. 134. Other examples may be seen in figs 125, 136, 154, 327, 330 and 394 .

${ }^{8}$ Others, too, suggest this meaning for the choice of style: Father Justin contrasts the dematerialized style of Peter as opposed to the classical manner in which the evangelists are painted (Nelson and Collins,
}

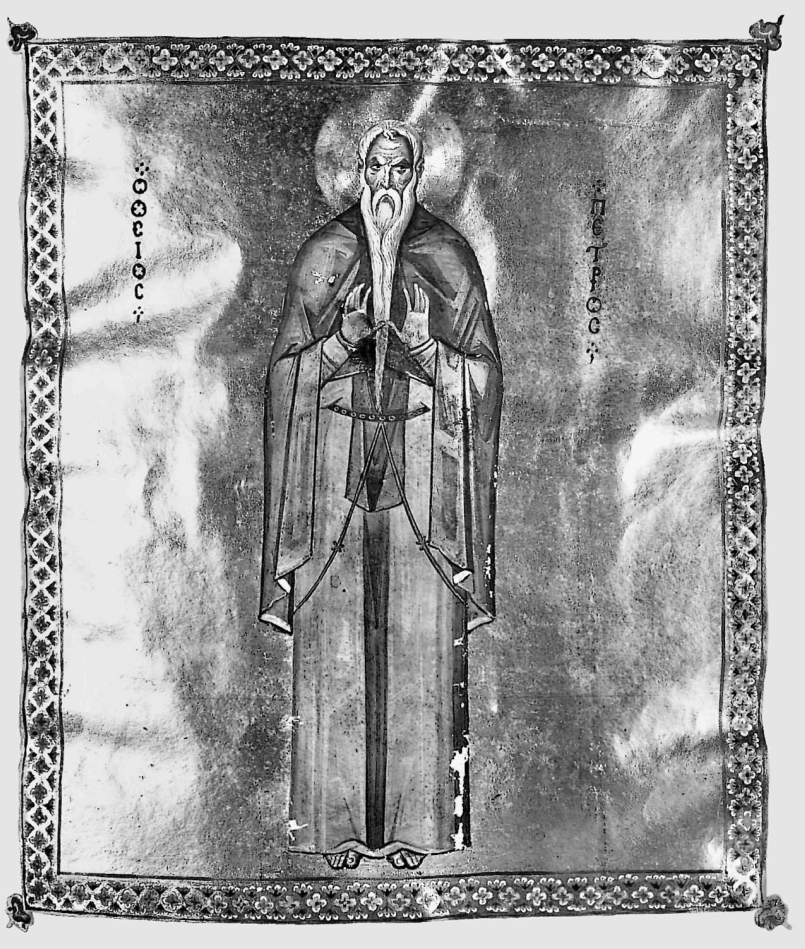

Fig. 2. Hosios Petrus, Sinai gr. 204, page 5, c. 1000 (Published through the courtesy of the Michigan-Princeton-Alexandria Expedition to Mt. Sinai).

emphasize the second rank of this holy man by the use of a distinct style. Such a use of different stylistic modes can be found in Byzantine painting as early as the sixth century, in the famed encaustic icon at Mt. Sinai'. While choices of different models does occur earlier, the figures copied are usually seen as living; here, it appears that the artist may have searched for a model from among portraits of deceased saints, a choice rarely encountered in Byzantine art.

The portrait of the Virgin (Fig. 1) is another unusual example of the innovative use of models in Sinai gr. 204. Standing in contrapposto turned slightly to her left, she is depicted holding a rolled scroll in her left hand. A recent discussion of

op.cit., 67); Manafis writes of "...the spirituality of Peter of Monobata is both revealed and stressed by a linear design. His body is indeed hidden under the monastic garb" (Manafis, op.cit., 314), and Weitzmann and Galavaris state, "Spirituality is stressed here by linear design and austere expression" (Weitzmann and Galavaris, op.cit., 46). The latter sources cited above also stress similarities to the physiognomy of St. Euthymios (Manafis, op.cit., 314; Weitzmann and Galavaris, op.cit., 45).

${ }^{9}$ See K. Weitzmann, The Icon, New York 1978, pl. 2. 


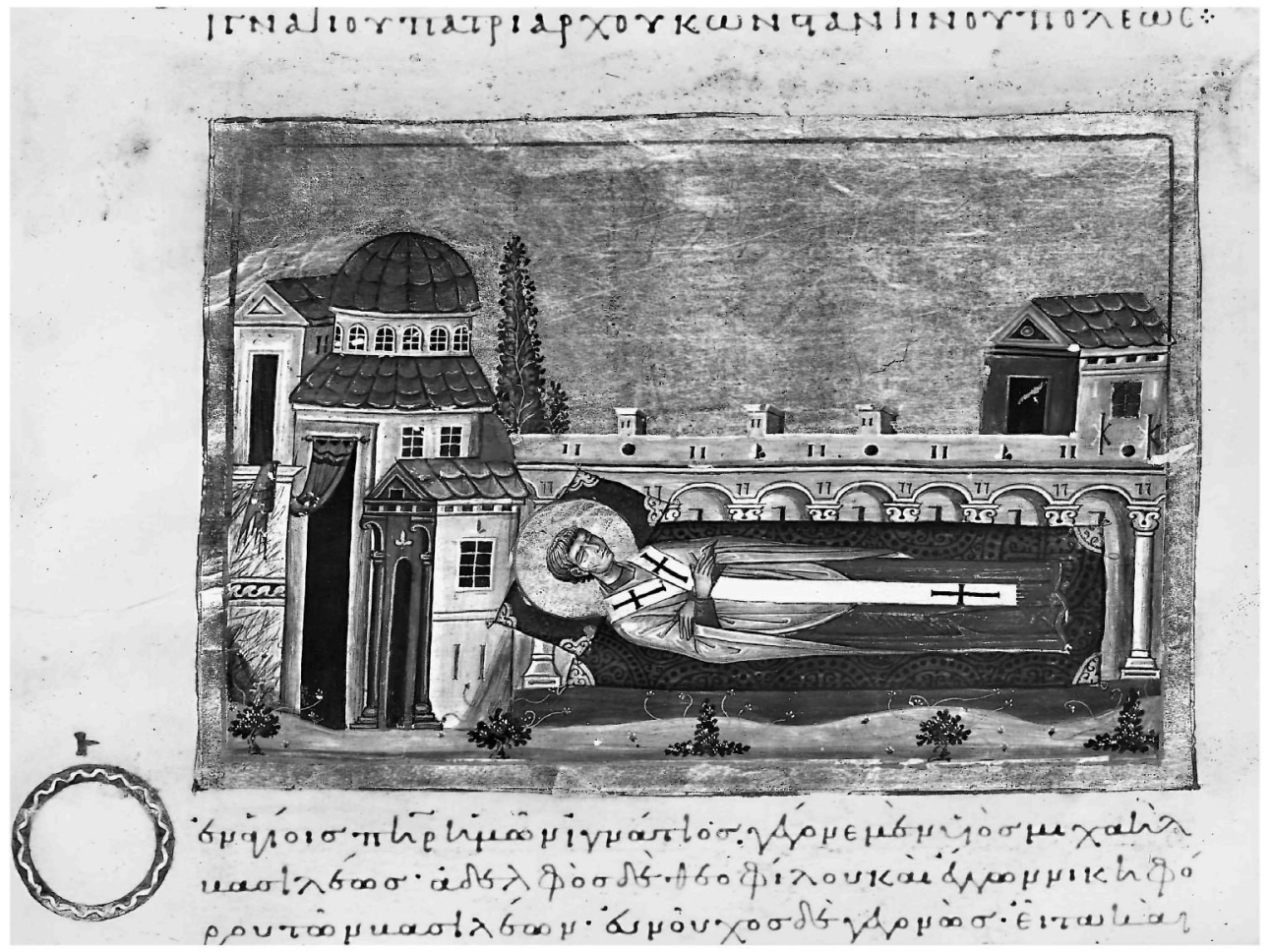

Fig. 3. St. Ignatius of Constantinople, Vatican gr.1613, 134, c. 985 (Courtesy of the Biblioteca Apostolica Vaticana).

this manuscript posited that the inclusion of the scroll underscored the Virgin praised as, "Christ's living book, sealed with the spirit," and as "the tablets inscribed both the hand of God, in which the Logos of God, having been written in..." ${ }^{10}$. This type of Virgin portrait is very rare. The more numerous scroll-bearing Virgins, exemplified by the famous Virgin of Spoleto icon from the early twelfth century, belong to a different type. Depicted in three-quarters pose turning to the right, this type displays an open scroll with a versified inscription. Due to the inscription and postural similarities to the Virgin of the Deesis, this version reinforces the meaning of the Virgin as intercessor; it has been related by Der Nersessian to the Virgin Hagiosoritissa image ${ }^{11}$. What, then, is the source for the Sinai Virgin? It is possible that the im-

\footnotetext{
${ }^{10}$ Quoted in Nelson and Collins, op.cit., 66.

$11 \mathrm{~S}$. Der Nersessian, "Two Images of the Virgin in the Dumbarton Oaks Collection", DOP 14 (1960), 81-85.

${ }^{12}$ Such a figure resembling a scroll-bearing Virgin is seen in the miniature of Solomon and the prophet Jesus Sirach from Codex 6 in Copen-
}

age was modeled after a lost illustration of the Canticles, or adapted from a representation of a personification, such as Virtue, Wisdom, Faith, or Prophecy ${ }^{12}$. A close examination of the actual figure, however, suggests quite another solution.

In viewing the image, the contrast between the exquisite painting of the rest of the miniatures and the rendering of the Virgin's hand holding the scroll is marked. The left hand shows a surprising weakness. Compared to her right hand, the left appears too small. It is attached to the wrist at an anatomically impossible angle. Its boneless structure is unconvincing, and the shading ineffective in defining its three-dimensional form. What occasioned such a marriage of good and poor painting in the same miniature could only

hagen (fol. 83v) from the middle or second half of the tenth century. She is usually identified as a personification of Holy Wisdom. See W. F. Volbach and $\mathbf{J}$. Lafontaine-Dosogne, Byzanz, Propyläen Kunstgeschichte, 3, Berlin 1968, 187 and pl. XVII. 
be the adaptation of an existing model: where the artist was working from the exemplar, his work was excellent; where he was inventing on his own, it was far less so. And the model chosen required adaptation only of the left hand, precisely that part which is weak in the miniature. The pose of the Virgin and the gesture of her right hand clearly indicate that the original model was a Virgin Hodegetria, the Virgin as "Indicator of the Way". In this type, the standing Virgin supports the Christ child with her left arm and points to him with with her right hand, indicating him as the way to salvation. A mid-tenth century ivory from the Archiepiscopal Museum, Utrecht, shows the standard features of this type $^{13}$. As in this example, the Child often carries a scroll; this may have provided some inspiration for the artist's solution in the Sinai miniature. The Christ child in the original was replaced by the scroll in the Sinai manuscript, necessi- tating the change in the position of the Virgin's hand, which the artist had to draw ad hoc. Perhaps, as there was already a portrait of Christ planned for the manuscript - indeed, on the preceding folio - a solo portrait of the Mother of God was deemed necessary ${ }^{14}$. As there are few of these which would be appropriate, a new type of portrait was created for this manuscript by the artist. His insecurity is betrayed by the contrast in competence within the picture itself.

The Sinai evangelion is one of the high points of middle Byzantine illumination. Its high quality and lavish use of gold suggest an imperial donation ${ }^{15}$. While it is clear that artists and ateliers working at this time relied heavily on the use of models, these two examples from Sinai gr. 204 show how, to solve a particular problem, an artist might skillfully adapt his models to create entirely new forms within the traditional canon of middle Byzantine art.

\section{Ellen C. Schwartz}

\section{ЕІКОNОГРАФІКЕ $\Sigma$ ПАРА $\Lambda$ АГЕ $\Sigma$

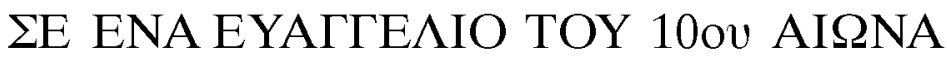

\section{$\mathrm{O}$}

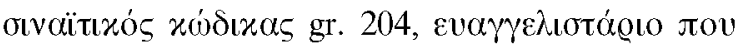

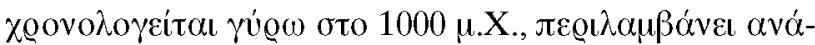

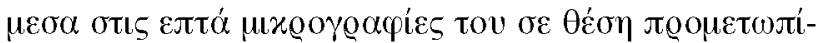

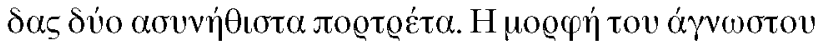

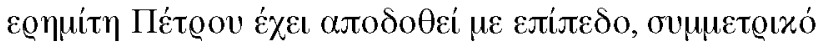

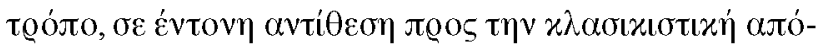

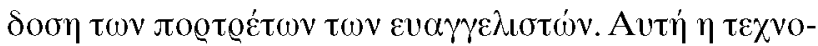

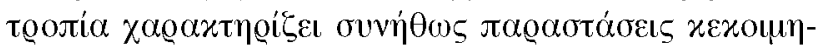

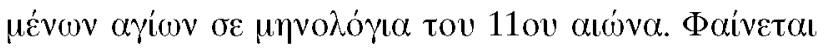

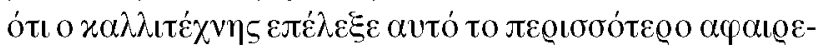

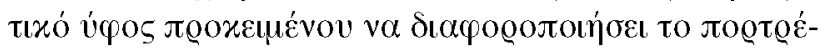

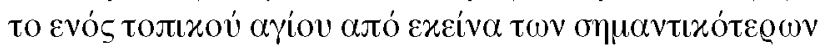

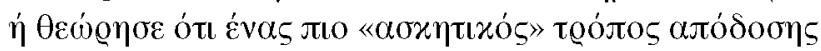

\footnotetext{
${ }^{13}$ For a color reproduction of the Utrecht ivory, see Weitzmann, op.cit. (n. 2), pl. 12.

${ }^{14}$ A similarly rare pair of illustrations (these from the later ninth century) is found in Princeton, Univ. Lib. cod. Garret 6, where the orant Virgin is pictured opposite Christ. See G. Vikan (ed.), Illuminated Manuscripts in American Collections, Princeton 1973, 52-55 and fig. 1. This
}

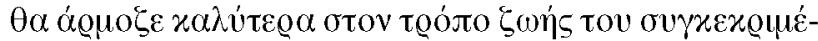
vov ayiov.

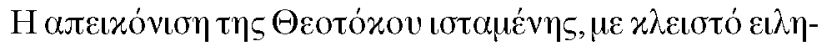

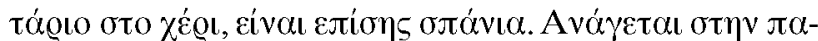

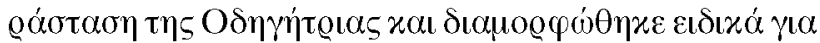

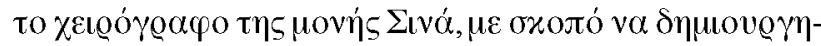

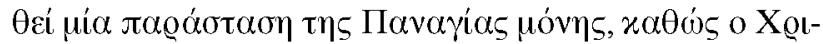

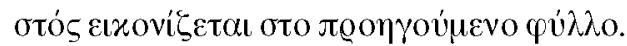

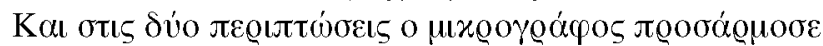

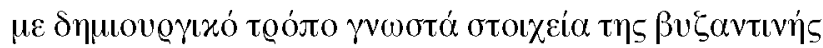

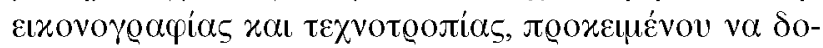

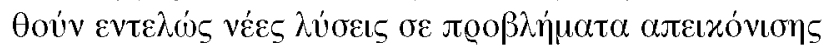

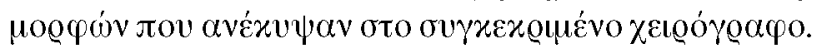

\footnotetext{
manuscript was most recently discussed in H.C. Evans and W.D. Wixom (eds), The Glory of Byzantium, Art and Culture of the Middle Byzantine Era A.D. 843-1261, exh. cat., New York 1997, as catalogue 43, 90-91.

${ }^{15}$ Beneshevic suggests Constantinople as its place of origin (Beneshevic, op.cit., 48). Weitzmann and Galavaris agree (Weitzmann and Galavaris, op.cit., 46).
} 